\title{
PENGEMBANGAN DESAIN PELATIHAN PENGUATAN USAHA MIKRO KECIL MENENGAH (UMKM) DI DESA WISATA
}

\author{
Fitriana Nurindah Kusumadewi \\ Program Studi Manajemen, Sekolah Bisnis dan Ekonomi, Universitas Prasetiya Mulya \\ fitriana.nkd@gmail.com
}

\begin{abstract}
Development of Training Design for Micro, Small and Medium Enterprises (MSME) Strengthening Program was prepared using the Dick and Carey model. To achieve this goal, research and development $(R \& D)$ methods are used. There are ten stages in the preparation of the design, starting from identifying instructional needs to conducting a summative evaluation. The results of the design are: (a) design of training for strengthening micro, small and medium enterprises (MSMEs) which refers to the stages of developing an instructional system, and (b) activities in training which are implemented as business strengthening programs to achieve capability and development goals.
\end{abstract}

Keywords: development, training design, MSME, tourist village, Dick \& Carey model model

\section{$A B S T R A K$}

Pengembangan Desain Pelatihan Program Penguatan Usaha Mikro Kecil Menengah (UMKM) ini disusun dengan menggunakan model Dick dan Carey. Untuk mencapai tujuan tersebut, digunakan metode penelitian research and development (R\&D). Terdapat sepuluh tahap dalam penyusunan rancangan, dimulai dari mengidentifikasi kebutuhan instruksional sampai dengan melakukan evaluasi sumatif. Hasil rancangan berupa: (a) desain pelatihan penguatan usaha mikro kecil menengah (UMKM) yang mengacu pada tahapan pengembangan sistem instruksional, dan (b) aktivitas dalam pelatihan yang diterapkan sebagai program penguatan usaha untuk mencapai tujuan capaian kemampuan serta pengembangan.

Kata kunci: pengembangan, desain pelatihan, UMKM, desa wisata, model Dick \& Carey

\section{PENDAHULUAN}

Pelatihan merupakan sebuah usaha sadar yang dilakukan dalam rangka memberikan penguatan dalam aspek tertentu. Sebagai sebuah konsep, pelatihan bertujuan meningkatkan pengetahuan dan keterampilan pembelajar (sasaran didik), agar mampu berkembang dan mandiri. Perkembangan model pelatihan (empowering, capacity building, magang, dan lain sebagainya) saat ini tidak hanya sebatas pada penyampaian ilmu karena kebutuhan akan kesempatan belajar menjadi semakin luas. Model pelatihan pada awalnya ada pada dunia usaha magang tradisional, di dalamnya terdapat kegiatan belajar mengajar yang dilakukan oleh pembelajar (sasaran didik) dan seorang pengajar/tutor (seorang sumber belajar). Dalam perkembangan berikutnya, interaksi edukatif yang terjadi tidak hanya melalui perorangan melainkan berkelompok yang memiliki kebutuhan dan tujuan belajar yang sama.

Di dalam dunia usaha, model pelatihan dirancang atas dasar kebutuhan peningkatan kapasitas, misalnya: menambah produksi, meningkatkan kemampuan pengelolaan, memperluas pemasaran, atau membuat awareness tentang usaha yang dijalankan. Perkembangan pelatihan ini melahirkan model-model yang sederhana sampai dengan yang kompleks mengikuti perkembangan zaman dan budaya yang berjalan di masyarakat. Suatu model pelatihan dianggap efektif ketika dilandasi dilandasi kurikulum, 
pendekatan dan strategi yang sesuai dengan kebutuhan pelaku usaha dan mampu menjawab permasalahanpermasalahan yang terjadi di dalamnya. Untuk itu diperlukan perhatian khusus dalam menyusun sebuah model pelatihan yang efektif dan efisien sehingga pelatihan yang dijalankan benar memberikan dampak penguatan yang membuat usaha berkembang. UMKM dari segi usaha pengelolaan, memiliki hubungan erat dengan perekonomian masyarakat di berbagai lapisan. Kenyataannya bidang usaha ini mengalami peningkatan setiap tahunnya, terlihat dari data Posisi Kredit Usaha Mikro, Kecil, dan Menengah (UMKM) pada bank umum di website Badan Pusat Statistik yang dapat diakses di https://www.bps.go.id/indicator/13/1962 /1/posisi-kredit-usaha-mikro-kecil-danmenengah-umkm-sup-1-sup-pada-bankumum-.html yang tersaji data berikut:

Tabel 11 Posisi Kredit UMKM pada Bank Umum

\begin{tabular}{|l|c|c|c|}
\hline UMKM & \multicolumn{3}{|c|}{ Posisi Kredit UMKM pada Bank Umum (Milyar Rupiah) } \\
\hline \multicolumn{1}{|c|}{ Tahun } & 2017 & 2018 & 2019 \\
\hline Mikro & 207682 & 236868 & 283518 \\
\hline Kecil & 269162 & 298065 & 343245 \\
\hline Menengah & 406138 & 435039 & 480477 \\
\hline
\end{tabular}

Sumber

URL:

https://www.bps.go.id/indicator/13/1962 /1/posisi-kredit-usaha-mikro-kecil-danmenengah-umm-sup-1-pada-bankumum-.html (diakses 16 Juli 2021)

Hal ini menjadi bukti kuat bahwa masyarakat memiliki minat untuk menjalankan UMKM dengan baik. Menjadi roda penggerak perekonomian Indonesia tentunya perlu mendapat kesempatan peningkatan yang besar, yang lebih dari pemberian sebuah pelatihan. Sejalan dengan penelitian yang dilakukan Mohamad Nur Singgih (Singgih, 2006: 7) menyimpulkan strategi penguatan UMKM yang secara umum memiliki peran dalam perekonomian nasional: (1) sebagai pemeran utama dalam kegiatan ekonomi, (2) penyedia lapangan kerja terbesar, (3) pemain penting dalam pengembangan perekonomian lokal dan pemberdayaan masyarakat, (4) pencipta pasar baru dan sumber inovasi, serta (5) kontribusinya terhadap neraca pembayaran.

Selain usaha pada UMKM, himpunan yang teroragnisir pada potensi desa wisata juga menjadi salah satu sumber peningkatan perekonomian dan kesejahteraan masyarakat Indonesia. Desa wisata biasanya dikembangkan pada pedesaan yang di dalamnya masih memiliki karakteristik khusus. Karakteristik yang dimiliki pada desa wisata adalah sumber daya alam yang masih asli, keunikan desa, tradisi dan budaya masyarakat lokal. Berbagai karakter tersebut menjadi citra suatu wilayah. Di dalam desa wisata, para UMKM dapat memberikan variasi kekhasan yang unggul seperti misalnya bidang kuliner, kriya, fashion, ataupun berbagai bidang jasa. Banyaknya potensi yang ada di desa wisata akan mengundang banyak wisatawan untuk melakukan perjalanan wisata. Wisatawan yang berkunjung akan memberikan kesempatan bagi masyarakat lokal untuk lebih mandiri dalam mensejahterakan kehidupannya melalui penjualan produk dan penyediaan jasa yang diciptakan dari berbagai potensi yang dipunyai. Untuk itu penguatan usaha yang berada dalam desa wisata ini perlu dipikirkan lebih jauh lagi.

Terlebih di masa pandemi ini, pengembangan model pelatihan dalam rangka penguatan UMKM sangat diperlukan. Hal ini sesuai dengan yang disammpaikan Lukman Hakim dalam Webinar Series bertajuk Strategi Penguatan UMKM Di Tengah Masa Pandemi yang diselenggarakan Riset Group Fiskal dan Moneter Fakultas Ekonomi dan Bisnis (FEB UNS), Kamis, 13 Agustus 2020 (sumber: https://feb.uns.ac.id/feb/strategipenguatan-umkm-di-tengah-masapandemi/) menyoroti paradigma baru UMKM sebagai by design. Disampaikan bahwa, "Paradigma baru UMKM sebagai by design, seharusnya UMKM disiapkan benar-benar, dibina sejak kecil menjadi menengah hingga besar. Pemerintah dengan anggarannya mempunyai kapasitas untuk itu, bisa bekerja sama 
dengan PT, swasta, technopark dan lainnya."

\section{KAJIAN LITERATUR}

\section{Desain Pelatihan}

Proses desain pelatihan mengacu pada pendekatan sistematik untuk mengembangkan program pelatihan. Desain pelatihan berkaitan dengan penyusunan program pelatihan yang mempertimbangkan aspek organisasi, pekerjaan, dan individu (Noe \& Kodwani, 2018).

Desain pelatihan berkaitan dengan penyusunan program pelatihan yang mempertimbangkan aspek organisasi, pekerjaan dan individu (Hariyanto, Purnomo, \& Bawono, 2011).

Menurut Gagnon dan Collay (2001), istilah desain pelatihan mengacu pada keseluruhan struktur dan urutan atau sistem kegiatan pelatihan. Selain itu, desain pelatihan dapat diartikan proses perencanaan yang sistematis sebelum pengembangan atau pelaksanaan kegiatan pelatihan. Konsep desain pelatihan diekspresikan dalam bentuk model. Model menggambarkan proses atau unit konseptual dengan komponen yang saling terkait. Model desain pelatihan adalah alat konseptual yang digunakan untuk menganalisis, merancang, menghasilkan, melaksanakan, dan mengevaluasi kegiatan atau rencana pelatihan.

Dari pendapat para ahli di atas dapat diketahui bahwa kegiatan pelatihan merupakan suatu susunan yang terencana dan tertata sistematis untuk mencapai tujuan pembelajaran atau suatu pengembangan yang ingin dicapai.

\section{Hakikat Pelatihan}

Pengembangan sumber daya manusia adalah upaya untuk meningkatkan kemampuan karyawan dalam kaitannya dengan kegiatan ekonomi yang dapat membantu karyawan dalam memahami pengetahuan praktis dan penerapannya untuk meningkatkan keterampilan, keterampilan dan sikap yang dibutuhkan organisasi dalam mencapai tujuannya juga disesuaikan dengan tuntutan pekerjaan yang harus dilakukan oleh seorang karyawan melalui pengembangan sumber daya manusia (Riyanto, Yanti, \& Ali, 2017).

Menurut Greenberg (2010:116) pelatihan adalah suatu proses dimana orang-orang secara sistematis memperoleh dan meningkatkan keterampilan dan kemampuan yang dibutuhkan untuk meningkatkan kinerja mereka.

Sedangkan menurut Dessler (2011:292) pelatihan berarti memberikan karyawan baru maupun karyawan lama keterampilan yang mereka butuhkan untuk melakukan pekerjaan mereka.

Pelatihan memiliki orientasi usaha menguasai suatu keterampilan dan kemampuan tertentu yang dibutuhkan untuk menjadi sukses. Hakikatnya pelatihan didefinisikan sebagai upaya terencana oleh sebuah organisasi untuk memfasilitasi pembelajaran perilaku yang berhubungan dengan pekerjaan/usaha terkait. Dari definisi di atas telah tergambar pelatihan sebagai upaya terencana oleh sebuah organisasi untuk memfasilitasi pembelajaran perilaku yang berhubungan dengan pekerjaan terkait yang menjadi bagian dari karyawan.

\section{Hakikat Penguatan}

Menurut Marno dan Idris (2010: 135) menyatakan bahwa ada beberapa komponen dalam memberikan penguatan yang perlu dipahami dan dikuasai oleh guru. Hal ini akan membuat guru menjadi bijaksanan dan sistematis dalam pelaksanaannya. Penguatan verbal dapat diberikan dengan komentar guru berupa kata-kata pujian, dukungan, dan pengakuan sebagai penguatan tingkah laku dan kinerja siswa. Komentar tersebut merupakan umpan balikan (feedback) yang dapat dilakukan oleh guru atas kinerja ataupun perilaku siswa.

Penguatan ialah respon positif dalam pembelajaran yang diberikan guru terhadap perilaku peserta didik yang positif dengan tujuan mempertahankan dan meningkatkan perilaku tersebut. Penguatan merupakan respon terhadap 
suatu tingkah laku yang sengaja diberikan agar tingkah laku tersebut dapat terulang kembali. Penguatan yang diberikan oleh guru merupakan hal yang sangat penting bagi peserta didik (Barnawi \& Arifin, 2012:208).

Selanjutnya menurut Moh. Uzer Usman dalam Menjadi Guru Profesional (2008:80), penguatan (reinforcement) adalah segala bentuk respon, apakah bersifat verbal maupun nonverbal, yang merupakan bagian dari modifikasi tingkah laku guru terhadap tingkah laku siswa, yang bertujuan untuk memberikan informasi atau umpan balik (feedback) bagi si penerima (siswa) atas perbuatannya sebagai suatu tindak dorongan maupun koreksi.

Dari beberapa definisi penguatan tersebut, dapat disimpulkan bahwa penguatan merupakan segala bentuk respon positif pendidik terhadap perkembangan peserta didiknya. Penguatan merupakan bagian dari modifikasi yang dapat meningkatkan kemungkinan berulangnya kembali tingkah laku tersebut atau mengalami peningkatannya. Melalui proses penguatan, perasaan besar hati dapat meningkatkan partisipasi peserta didik dalam setiap proses pembelajaran.

\section{Usaha Mikro Kecil Menengah (UMKM)}

Sesuai dengan Undang-Undang Nomor 20 Tahun 2008 dalam UndangUndang Usaha Mikro, Kecil dan Menengah (2013: 3), pengertian Usaha Mikro Kecil dan Menengah (UMKM) adalah:

1) Usaha mikro adalah usaha produktif milik orang perorangan dan/atau badan usaha perorangan yang memenuhi kriteria usaha mikro sebagaimana diatur dalam undangundang ini.
2) Usaha kecil adalah usaha ekonomi produktif yang berdiri sendiri, yang dilakukan oleh orang perorangan atau badan usaha yang bukan merupakan anak perusahaan atau bukan cabang perusahaan yang dimiliki, dikuasai, atau menjadi bagian baik langsung maupun tidak langsung dari usaha menengah atau usaha besar yang memenuhi kriteria usaha kecil sebagaimana dimaksud dalam undang-undang ini.

3) Yang dimaksud usaha kecil dan menengah adalah kegiatan usaha dengan skala aktivitas yang tidak terlalu besar, manajaemen masih sangat sederhana, modal yang tersedia terbatas, pasar yang dijangkau juga belum luas.

4) Usaha menengah adalah usaha ekonomi produktif yang berdiri sendiri, yang dilakukan oleh orang perseorangan atau badan usaha yang bukan merupakan anak perusahaan atau cabang perusahaan yang dimiliki, dikuasai, atau menjadi bagian baik langsung maupun tidak langsung dengan usaha kecil atau usaha besar dengan jumlah kekayaan bersih atau hasil penjualan tahunan sebagaimana diatur dalam undangundang ini.

5) Kata lain dari pelaku usaha adalah wirausahawan (entrepreneuship). Secara sederhana, wirausahawan (entrepreneuship) dapat diartikan sebagai pengusaha yang mampu meliat peluang dengan mencari dana serta sumber daya lain yang diperlukan untuk menggarap peluang tersebut, berani menanggung risiko yang berkaitan dengan pelaksanaan bisnis yang ditekuninya, serta menjalankan usaha tersebut dengan rencana pertumbuhan dan ekspansi.

Menurut Tambunan, Tulus (2012:11) UMKM merupakan sebuah unit usaha produktif yang berdiri sendiri, yang dilakukan oleh orang perorangan atau badan usaha di semua sektor ekonomi. Pada prinsipnya, pembedaan antara Usaha Mikro (UMI), Usaha Kecil (UK), Usaha Menengah (UM), dan Usaha 
Besar (UB) umumnya didasarkan pada nilai aset awal (tidak termasuk tanah dan bangunan), omset rata-rata per tahun, atau jumlah pekerja tetap. Namun definisi UMKM berdasarkan tiga alat ukur ini berbeda menurut negara. Karena itu, memang sulit membandingkan pentingnya atau peran UMKM antar negara.

Dalam perspektif perkembangannya, Usaha Mikro Kecil dan Menengah (UMKM) merupakan kelompok usaha yang memiliki jumlah paling besar. Selain itu kelompok ini terbukti tahan terhadap berbagai macam goncangan krisi ekonomi. Maka sudah menjadi keharusan penguatan kelompok Usaha Mikro Kecil dan Menengah yang melibatkan banyak kelompok. Berikut ini adalah klasifikasi Usaha Mikro Kecil dan Menengah (UMKM) yang dilakukan Ade Resalawati (2011:11):

1) Livelhood Activities, merupakan Usaha Mikro Kecil dan Menengah (UMKM) yang digunakan sebagai kesempatan kerja untuk mencari nafkah, yang labih umum biasa disebut sektor informal. Contohnya pedagang kaki lima.

2) Micro Enterprise, merupakan Usaha Mikro Kecil dan Menengah (UMKM) yang memiliki sifat pengrajin tetapi belum memiliki sifat kewirausahaan.

3) Small Dynamic Enterprise, merupakan Usaha Mikro Kecil dan Menengah (UMKM) yang telah memiliki jiwa kewirausahaan dan mampu menerima pekerjaan subkontrak dan ekspor.

4) Fast Moving Enterprise, merupakan Usaha Mikro Kecil dan Menengah (UMKM) yang telah memiliki jiwa kewirausahaan dan akan melakukan transformasi menjadi usaha besar (UB).

Menurut berbagai pemahaman di atas, maka UMKM merupakan usaha kecil yang berkutat di berbagai sector produk dan jasa. Sesuai namanya, ada tiga jenis usaha yang termasuk dalam UMKM, yaitu usaha mikro, kecil, dan menengah.
Ketiganya memiliki definisi dan kriteria yang berbeda namun memiliki kesamaan yaitu menjadi salah satu sumber pendapatan negara serta pencipta lapangan pekerjaan bagi masyarakat Indonesia.

\section{Desa Wisata}

Salah satu upaya untuk mewujudkan keunggulan yang menyejahterakan adalah dengan mengembangkan desa wisata. Menurut Nuryanti (Dalam Yuliati \& Suwandono, 2016) desa wisata merupakan wujud kombinasi antara atraksi, akomodasi, dan fasilitas pendukung yang dikemas dalam suatu pola kehidupan masyarakat yang menyatu dengan tata cara dan tradisi yang berlaku sehingga menjadikan desa tersebut sebagai tujuan wisata. Desa wisata adalah bentuk industri pariwisata yang berupa kegiatan perjalanan wisata identik meliputi sejumlah kegiatan yang bersifat mendorong wisatawan sebagai konsumen agar menggunakan produk dari desa wisata tersebut atau melakukan perjalanan wisata ke desa wisata. Unsur produk pariwisata terdiri dari angkutan wisata, atraksi wisata, dan akomodasi pariwisata.

Merupakan pengembangan suatu wilayah desa yang pada dasarnya tidak merubah apa yang sudah ada akan tetapi lebih cenderung kepada pengembangan potensi desa yang ada dengan melakukan pemanfaatan kemampuan unsur- unsur yang ada di dalam desa yang berfungsi sebagai atribut produk wisata dalam skala yang kecil menjadi rangkaian aktivitas atau kegiatan pariwisata dan mampu menyediakan serta memenuhi serangkaian kebutuhan perjalanan wisata baik dari aspek daya tarik maupun sebagai fasilitas pendukung (A.J, Muljadi, 2012:12).

Desa wisata adalah suatu bentuk perkembangan pariwisata yang menitik beratkan pada kontribusi masyarakat sekitar pedesaan dan pelestarian lingkungan area pedesaan. Desa wisata memiliki produk wisata yang benilai budaya dan memiliki karakteristik traditional yang kuat (Fandeli, Baiquni, Dewi, 2013:131) 
Dari berbagai definisi mengenai desa wisata di atas dapat disimpulkan bahwa kegiatan wisata yang dilakukan pada obyek wisata desa. Maka, desa wisata adalah obyek dan wisata desa adalah kegiatannya. Berdasarkan atas beberapa pendapat para ahli di atas, dapat dijelaskan bahwa desa wisata merupakan suatu wilayah yang menjadi obyek yang memiliki ciri khas keindahan alam, seni budaya, atau kebiasaan masyarakat sehari-hari yang mana para wisatawan dapat ikut terjun langsung merasakan kehidupan sesuai karakteristik masyarakat di desa tersebut.

\section{METODE PENELITIAN}

Berdasarkan fokus perancangan, yakni pengembangan desain pelatihan pada penguatan usaha mikro kecil menengah (UMKM) desa wisata, prosedur yang ditempuh menggunakan metode pengembangan. Metode yang digunakan yaitu metode Penelitian dan Pengembangan atau dalam literatur aslinya disebut dengan Research and Development (R\&D) adalah metode penelitian yang digunakan untuk menghasilkan produk tertentu, dan menguji keefektifan produk tersebut. Penelitian dilaksanalan pada Maret samapi dengan Juni 2021.

Di dalam literatur ditemukan sejumlah model pengembangan sistem instruksional, salah satunya adalah model Dick dan Carey. Suradika dkk (2020) menyatakan bahwa model Dick dan Carey merupakan model yang berorientasi kepada kebutuhan peserta dengan menggunakan pendekatan sistem. Dalam siklus yang dibuat oleh Dick dan Carey terdapat sepuluh tahapan pengembangan bahan instruksional yang dirancang setelah ditetapkannya strategi instruksional (Dick dan Carey, 2009: 136, 168). Model ini termasuk ke dalam model yang berorientasi kepada proses. Saat merancang model pelatihan dengan model Dick and Carey, harus terlebih dahulu menentukan tujuan pelatihan secara umum. Sebelum menetapkan tujuan, perlu menganalisis pembelajaran pada pelatihan dan menentukan kemampuan awal peserta terlebih dahulu.
Selanjutnya perlu dikembangkan strategi pembelajaran dengan harapan dapat mencapai tujuan terbaik, kemudian menulis bahan ajar berdasarkan tujuan tersebut. Tahap terakhir dari perancangan adalah melakukan penilaian, yaitu membentuk evaluasi serta ringkasan evaluasi. Berikut alur desain pelatihan yang dikembangkan oleh Dick and Carey:

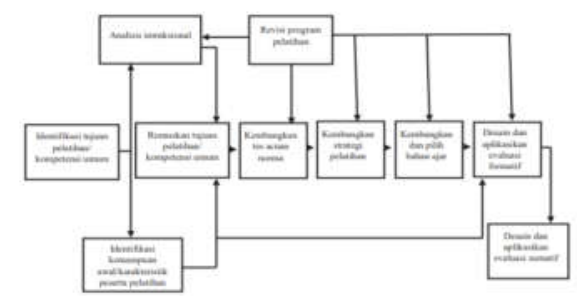

Bagan 3 model pengembangan Dick \& Carey

Prosedur pengembangan pada penelitian ini menurut model Dick \& Carey yaitu:

1) Identifikasi Tujuan (Identity Instructional Goals)

2) Melakukan Analisis Instruksional (Conducting a goal Analysis)

3) Mengidentifikasi Tingkah Laku Awal/ Karakteristik (Identity Entry Behaviors, Characteristic)

4) Merumuskan Tujuan Kinerja (Write Performance Objectives)

5) Pengembangan Tes Acuan Patokan (developing criteria-referenced test items)

6) Pengembangan Strategi Pengajaran (develop instructional strategy)

7) Pengembangan atau Memilih Pengajaran (develop and select instructional materials)

8) Merancang dan Melaksanakan Evaluasi Formatif (design and conduct formative evaluation)

9) Menulis Perangkat dan Evaluasi Sumatif (design and conduct summative evaluation)

10) Revisi Pengajaran (instructional revisions)

\section{HASIL DAN PEMBAHASAN}


Dari adaptasi Research and Development (R\&D) yang diterapkan pengembang akan mendesain materi pembelajaran dan sistem pelatihan UMKM desa wisata. Hal yang pertama adalah merumuskan tujuan dari setiap kegiatan yang diselenggarakan. Selain itu perancang juga menentukan strategi pelatihan, menganalisis materi pembelajaran serta sistem evaluasi yang akan disesuaikan dengan target peserta didik/pembelajar.

Analisis ini dilakukan supaya langkah-langkah yang ditempuh dalam menerapkan desain pembelajaran dapat sistematis. Secara deskriptif, analisis model Dick \& Carey ini bila diinterpretasikan dalam 10 model pengembangannya menjadi berikut:

\section{Analisis Tujuan (Identity Instructional Goals)}

Melakukan analisis kebutuhan untuk menentukan tujuan program atau produk yang akan dikembangkan. Kegiatan analisis kebutuhan ini dengan cara mengidentifikasi kebutuhan prioritas yang bersifat perlu segera dipenuhi. Dengan mengkaji kebutuhan, pengembang akan mengetahui adanya suatu keadaan yang seharusnya ada (what should be) dan keadaan nyata di lapangan yang sebenarnya (what is). Dengan cara melihat kesenjangan atau gap yang terjadi, perancang mencoba menawarkan suatu alternatif pemecahan dengan cara mengembangkan suatu produk atau desain tertentu. Hal ini menegaskan bahwa berdasarkan analisis ini, perancang mengetengahkan suatu persoalan atau kesenjangan dan sekaligus menawarkan solusinya.

Melihat tujuan yang ingin dicapai pada kegiatan ini adalah pengupayaan UMKM agar dapat meningkatkan pengelolaan dalam usahanya terutama yang dapat juga mendongkrak desa wisata. Di era digital ini seharusnya para UMKM sudah bisa memanfaatkan sosial media sebagai strategi promosi, namun kenyataannya mereka belum memiliki literasi yang cukup mengenai penggunaan media promosi atau bahkan sekedar pembukuan keuangan usaha atau pengetahuan-pengetahuan tentang manajemen dalam usaha yang dijalankannya.

\section{Analisis Instruksional (Conduct Instructional Analysis)}

Perancang coba menggali hal-hal apa saja yang menjadi kebutuhan yang dirasakan untuk dipenuhi, perlu diidentifikasi dan selanjutnya diungkapkan dalam rancangan desain pelatihan yang ingin dikembangkan. Pengembangan mencakup ketrampilan, proses, prosedur, dan tugas-tugas belajar untuk mencapai tujuan pembelajaran. Timeline yang digunakan untuk menjabarkan kegiatan dalam rangka pemenuhan kebutuhan:

Tabel 12 Timeline Kegiatan

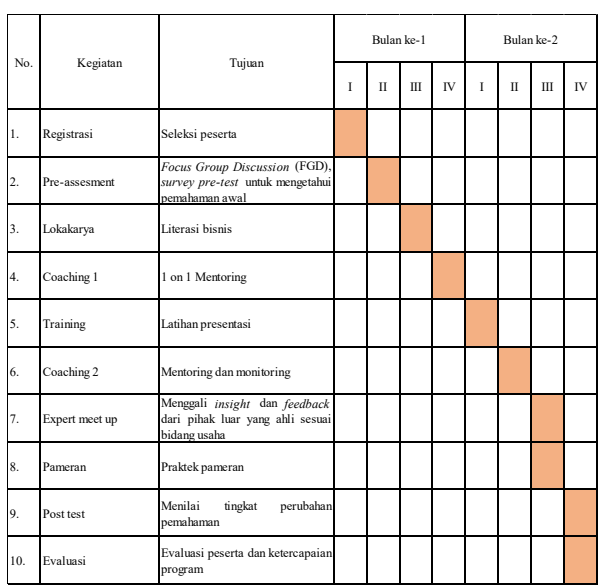

Adanya kegiatan expert meet up dan pameran menjadi kekhasan kegiatan tersendiri bahwa ujung rangkaian akhir dari kegiatan penguatan ini akan dibawa dan dinilai langsung ke pelaku industri yang sebenarnya sehingga kritik serta saran yang didapat lebih nyata dan dapat diaplikasikan di usaha yang dijalankan para UMKM.

\section{Analisis Karakteristik dan Konteks Pembelajaran (Analyze Learners and Contexts)}

Secara simultan analisis dapat dilakukan setelah menganalis pembelajar dan materi yang diperoleh, yang mencakup kemampuan, sikap, karakteristik awal pembelajar dalam latar pembelajaran. Dan juga termasuk karakteristik latar pembelajaran tersebut di mana pengetahuan dan keterampilan 
baru akan digunakan untuk merancang strategi instruksional.

Karakteristik pada pelaku UMKM ini dirancang untuk dikembangkan sesuai dengan topik-topik yang akan diajarkan dengan memperhatikan aspek latar belakang pendidikan, demografis, dan usia pelaku usaha. Karena latar belakang ini sangat berpengaruh untuk mengetahui bagaimana modal pemahaman dan berada dalam level mana pengembangan harus diberikan.

\section{Merumuskan Tujuan Khusus (Write Performance Objectives)}

$\begin{aligned} & \text { Tujuan ini secara spesifik } \\ & \text { memberikan informasi untuk }\end{aligned}$
mengembangkan butir-butir tes.
Pengembang melakukan penerjemahan
tujuan umum atau dari standar
kompetensi yang telah ditentukan ke
dalam tujuan khusus yang lebih
operasional dengan indikator-indikator
tertentu. Gambaran rumusan operasional
ini mencerminkan tujuan khusus
program atau produk, prosedur yang
dikembangkan.

Langkah awal setelah mendapat peserta dari hasil seleksi, adalah membuat rincian keadaan UMKM dalam survey pengisian pre-test. Pre-test ini berupa isian dalam butir-butir soal yang mencerminkan capacity building dalam praktek kewirausahaan, baik literasi bisnis maupun dalam pengelolaannya. Pre-test ini digunakan sebagai pedoman dalam pemberian materi pada lokakarya yang diberikan maupun coaching yang dijalankan. Ini juga sebagai database gambaran prosedur, operasional, serta sistem yang telah dikembangkan oleh maing-masing pelaku UMKM.

\section{Mengembangkan Instrumen (Develop Assesment Instruments)}

Pengembangan instrumen assessment secara langsung berkaitan dengan tujuan khusus dan operasional. Tugas mengembangkan instrumen ini menjadi sangat penting karena dalam hal ini bisa berkaitan dengan tujuan yang ingin dicapai berdasarkan indikator-indikator tertentu, dan juga instrumen untuk mengukur desain pelatihan yang dikembangkan. Instrumen yang berkaitan dengan tujuan khusus berupa tes hasil belajar, sedangkan instrumen yang berkaitan dengan perangkat produk atau desain yang dikembangkan dapat berupa kuesioner atau daftar cek.

Pre-assesment yang dilakukan mendatangi lokasi usaha adalah bentuk dari pengecekan atas usaha yang tengah dijalankan sekaligus konfirmasi bahwa yang telah diisi pada tahap registrasi sebagai seleksi kompetensi awal telah sesuai dengan yang diinginkan. Selain itu, dilakukan pula Focus Group Discussion (FGD) antar pengusaha di dalam desa wisata yang sama dengan keanekaragaman jenis, misalnya aneka olahan pagan, kopi, fashion, kriya, dan lain sebagainya yang dapat membuka pemahaman-pemahaman baru antar usaha serta keterkaitan satu sama lain dalam memajukan desa wisata setempat. Penanya dalam sesi assessment ini sudah membawa sejumlah daftar pertanyaan untuk dicek yang kemudian hasil temuan yang diperoleh dirangkum dalam matrix yang dapat diolah sebagai sumber informasi dan reflective note untuk perencanaan strategi penyusunan cara pengembangan masing-masing UMKM.

\section{Mengembangkan \\ Strategi Pembelajaran (Develop Instructional Strategy)}

Strategi pembelajaran yang dirancang ini juga berkaitan dengan produk atau desain yang ingin dikembangkan secara spesifik untuk membantu pembelajar untuk mencapai tujuan khusus.

Dengan penjadwalan lokakarya literasi bisnis, training presentasi, serta coaching yang disampaikan oleh para mentor di bidang usaha akan memberikan ilmu yang sesuai dengan kebutuhan. Literasi bisnis ini berupa beberapa aspek seperti: manajemen keuangan, manajemen operasional, manajemen sumber daya manusia, manajemen pemasaran, dan strategi. Pelatihan tentang teknik dan cara presentasi sendiri diberikan agar para pelaku UMKM dapat mengikuti kegiatan expert meet up untuk mempresentasikan produk atau usahanya. Coaching 
dilakukan berkala 2 kali dengan sistem 1 on 1 atau berhadapan 1 pelaku UMKM dengan 1 mentor yang mana dalam hal ini mentor merupakan pengajar di sekolah/perguruan tinggi sesuai dengan bidang yang diajarkannya.

\section{Mengembangkan dan Memilih Bahan Ajar (Develop and Select Instructional Materials)}

Mengembangkan dan memilih bahan pembelajaran merupakan salah satu hal yang penting. Karena pemilihan ini harus didasarkan pada kemampuan penggunaan dan ketersediaan oleh peserta. Pilihan media dan bahan ajar seperti misalnya: bahan cetak, media komunikasi digital, serta media lain yang dirancang untuk mendukung pencapaian tujuan. Perlu diberikan argumen atau alasan mengapa memilih dan mengembangkan berdasarkan tipe atau model yang dirancang khusus pada penerapan produk atau desain yang dikembangkan berdasarkan tipe, jenis, dan model tertentu tersebut.

Pengembangan dan pemilihan bahan ajar ditetukan dari keterjangkauan dan syarat kemampuan penggunaan sumbersumber belajar yang telah disampaikan pada saat registrasi sehingga peserta sudah mempersiapkan diri serta sarana prasarana pendukungnya. Bahan ajar yang dapat digunakan pada pelatihan ini adalah modul yang telah disusun oleh para mentor. Sedangkan aplikasi yang digunakan meliputi Microsoft Excel untuk latihan pembukuan; Canva untuk latihan membuat logo, visual merek, presentasi, serta desain konten media sosial; Google Bisnisku untuk mendaftarkan usaha dalam halaman pencarian Google; dan Media sosial seperti Facebook atau Instagram yang disesuaikan dengan kebutuhan. Sebagai sarana komunikasi selama penguatan usaha, kegiatan dapat dilakukan dengan cara tatap muka secara offline atau online dengan zoom dan streaming dengan Youtube.

\footnotetext{
Desain dan Evaluasi Formatif (Design and Conduct Formative Evaluation of Instruction)
}

Supaya dapat melihat keefektifan pembelajaran, perlu dirancang dan dilakukan evaluasi formatif yaitu evaluasi yang dilaksanakan oleh pengembang selama program penguatan berjalan. Pada tahap desain dan evaluasi ini dilakukan expert meet up serta pameran. Pada expert meet up, para pelaku UMKM diberikan kesempatan untuk mempresentasikan usaha produk/jasa yang dikelolanya agar mendapatkan umpan balik masukan dari para expertist pelaku usaha yang sudah lebih besar. Tidak menutup kemungkinan juga apabila para expertist memilih UMKM untuk diberikan peluang dana modal ataupun akses menjalin kerjasama. Pada kegiatan pameran, para pelaku UMKM diberikan kesempatan untuk melakukan display produk atau menyampaikan informasi kepada para pengunjung mengenai usaha yang ditawarkan, hal ini tentunya sebagai praktek mereka dalam menampilkan produk/jasa dan kesempatan untuk belajar mengemas agar menarik minat khalayak ramai dalam melakukan pembelian.

\section{Revisi Instruksional (Revise Instruction)}

Revisi dilakukan terhadap terhadap proses pelatihan selama program penguatan UMKM ini dijalankan. Hasil capaian dan masukan dari pihak luar seperti expertist atau masyarakat yang hadir dalam pameran dapat menjadi catatan dalam revisi atau pengukuran ketercapaian program pelatihan yang telah dijalankan. Apabila dirasa masih perlu maka akan dilakukan coaching atau training lanjutan bagi para pelaku UMKM yang belum dapat mengelola serta mencapai target secara optimal.

\section{Merancang dan Mengevaluasi Sumatif (Design and Conduct Summative Evaluation)}

Setelah proses rangakaian program penguatan dijalankan dari pelatihan hingga pelaksanaan pameran, langkah berikutnya adalah melakukan evaluasi sumatif. Evaluasi sumatif ini dilaksanakan dengan tujuan untuk menentukan tingkat efektivitas program, 
atau proses secara keseluruhan dibandingkan dengan program lain. Hasil-hasil pada tahap revisi instruksional dijadikan dasar untuk menulis perangkat yang dibutuhkan. Hasil perangkat tersebut selanjutnya divalidasi dan diujicobakan kepada para pelaku UMKM dengan adanya post-test. Peserta harus menjawab butir-butir pertanyaan kembali sesuai dengan pemahaman yang didapat setelah mendapatkan pelatihan. Pertanyaan yang diajukan dalam post-test sama dengan pre-test sehingga dari isiannya akan mudah diukur dan diketahui bagaimana kemajuan tingkat capacity building peserta setelah mendapatkan pelatihan.

\section{KESIMPULAN}

Dari pengembangan model pelatihan yang dilakukan dapat disimpulkan bahwa:

1) Pengembangan analisis model Dick \& Carey ini sangat tepat digunakan pada pengembangan pembelajaran yang berbasis keterampilan karena mengacu pada tahapan umum sistem instruksional rancang bangun desa wisata dan kelola UMKM.

2) Kolaborasi dibutuhkan untuk memperkuat daya tarik desa wisata yang dihimpun dari UMKM setempat. Kegiatan pelatihan dalam program penguatan usaha dapat dilakukan lebih dari sekedar pemberian materi mengenai literasi bisnis/kewirausahaan, tetapi juga dapat berlanjut pada pendampingan bersama mentor untuk mengaplikasikan ilmu yang telah di dapat dari pelatihan. Lebih jauh lagi dalam rangka penguatan usaha, pengembang model pelatihan juga dapat menyusun kegiatan yang melibatkan

expertist/pengusaha/praktisi yang sudah ahli untuk menguji dengan presentasi serta kesempatan mengadakan event pameran agar dapat mengukur seberapa dampak dari implementasi yang diperoleh dari pelatihan.

\section{DAFTAR PUSTAKA}

A.J, Muljadi. 2012. Kepariwisataan dan Perjalanan. Jakarta: Raja Grafindo Persada.

Barnawi \& Mohammad Arifin. 2012. Etika dan Profesi Kependidikan. Yogyakarta: Ar-Ruzz.

Dessler, Gary. 2011. Human Resource Management. New Jersey: Pearson Education, Inc.

Dewi, Fandeli, \& Baiquni. 2013. Pengembangan desa wisata berbasis partisipasi masyarakat lokal di Desa Wisata Jatiluwih. Jurnal Kawistara Vol.3.

Dick, Walter and Carey, Lou. 2009. The Systematic Design of Instruction. New Jersey: Pearson.

Gall,M.D., Gall J.P. \& Borg W.R. 2003. Educational research an introduction. $7^{\text {th }}$ edition. Boston: Pearson education, Inc.

Greenberg, Jerald. 2010. Managing Behavior in Organization. New Jersey: Pearson Education, Inc., 2010.

Hariyanto, Eko \& Purnomo, Ratno \& Rangga Bawono, Icuk. 2011. Desain Pelatihan, Dukungan Organisasional, Dukungan Supervisor dan Self-Efficacy sebagai Faktor Penentu Keefektifan Transfer Pelatihan. Jurnal Siasat Bisnis. https://journal.uii.ac.id/JSB/article /view/3217 diakses pada 16 Juli 2021 pukul 15:12

Marno dan Idris. 2010. Strategi dan Model Pengajaran. Yogjakarta: Media.

Moh. Uzer, Usman. 2008. Menjadi Guru Profesional. Bandung: PT Remaja Rosdakarya.

Noe, Raymond A., \& Kodwani, Amitabh Deo. 2018. Employee Training and Development. $7^{\text {th }}$ edition. New York: McGraw-Hill Education.

Resalawati, Ade. 2011. Pengaruh Perkembangan Usaha Kecil Menengah Terhadap Pertumbuhan Ekonomi Pada 
Sektor UKM Indonesia. (Skripsi: Fakultas Ekonomi dan Bisnis, Universitas Islam Negeri Syarif Hidayatullah Jakarta. https://repository.uinjkt.ac.id/dspa ce/handle/123456789/247 diakses pada 16 Juli 2021 pada 16.21

Riyanto, Setyo, Yanti, Ria Rahma, \& Ali, Hapzi. 2017. The Effect of Training and Organizational Commitment on Performance of State University of Jakarta Student Cooperative (KOPMA UNJ) Management.

Yogyakarta: Education Science.

Singgih, M. N. 2006. Strategi Penguatan Usaha Mikro Kecil Menengah (Umkm) Sebagai Refleksi Pembelajaran Krisis Ekonomi Indonesia. Jurnal Ekonomi Modernisasi, 3(3), 218-227. https://ejournal.unikama.ac.id/ind ex.php/JEKO/article/view/948 diakses pada 16 Juli 2021 pukul 15.50

Suradika, A., Winata, W., Wicaksono, D., Hadi, M. S., \& Rifqiyati. 2020. The Influence of Instructional Materials and Educational Background on the Learning Outcomes of Islamic Education. Solid State Technology, 63(6), 1027-1043.

http://solidstatetechnology.us/inde x.php/JSST/article/view/2185

Tulus Tambunan. 2012. Usaha Mikro Kecil dan Menengah di Indonesia: Isu-Isu Penting. Jakarta: LP3ES.

Undang-Undang Usaha Mikro, Kecil dan Menengah. 2013. Yogyakarta: Pustaka Mahardika.

Yuliati, E., \& Suwandono, D. 2016. Arahan Konsep dan Strategi Pengembangan Kawasan Desa Wisata Nongkosawit Sebagai Destinasi Wisata Kota Semarang. Jurnal LPPMP Undip: Ruang, 2(4), 263-272. https://doi.org/10.14710/ruang.2.4 $.263-272$ 